\title{
PEMBUATAN PROTOTYPE CANTING ELEKTRIK “CANTRIK” BERDASARKAN KARAKTERISTIK KEBUTUHAN PENGGUNA DENGAN METODE QUALITY FUNCTION DEPLOYEMENT (QFD)
}

\author{
Siti Lestariningsih \\ Program Studi Teknik Industri Universitas Widya Mataram Yogyakarta \\ e-mail: siti_lestariningsih@yahoo.com
}

\begin{abstract}
ABSTRAK
Penggunaan canting tradisional yang sulit bagi pemula sebagai dasar Balai Besar Kerajinan dan Batik (BBKB) membuat penelitian tentang Canting Elektrik (Cantrik) namun hasilnya masih terdapat kekurangan, sehingga dilakukan penelitian tentang pembuatan prototype Cantrik berdasarkan keinginan pengguna. Dalam membuat perancangan prototype baru penentuan atribut-atribut sesuai dengan keinginan pengguna dengan menggunakan metode Quality Function Deployement (QFD). Penelitian ini dengan membagikan kuesioner kepada 35 orang responden (pengguna) sebagai sampel sebagai dasarkan dalam pembuatan prototype Cantrik baru. Hasil penelitian Prototype Cantrik baru mempunyai diemeter sebesar 4,8 mm dan panjang 200,02 mm dan setelah dilakukan percobaan bahwa hasil goresan "ngawat" hal ini sesuai dengan penggunaan canting tradisional, penggunaannya lebih mudah, tempat lebih bersih tetapi masih sedikit panas.
\end{abstract}

Kata Kunci: Quality Fuction Deployment (QFD), Canting Elektrik, Prototype.

\begin{abstract}
The use of traditional canting difficult for beginners as the basis for the Balai Besar Kerajinan dan Batik (BBKB) made a research on Canting Electric (cantrik), but the result is still a shortage, so do research on a prototype Canting Electric based on the wishes of the user. In making the determination of the new prototype design to attributes the user's wishes by using Quality Function deployment (QFD). This research by distributing questionnaires to 35 respondents (users) as samples as the basis of the prototype new Canting Electric. Results of a new study Canting Electric Prototype has diameter of $4.8 \mathrm{~mm}$ and a length of $200.02 \mathrm{~mm}$ and after the trial that the result of scratches "ngawat" this is in accordance with the use of traditional canting, use easier, cleaner place but still a little hot.
\end{abstract}

Keywords: Quality Function Deployment (QFD), Canting Elektrik, Prototype

\section{PENDAHULUAN}

Batik tulis tradisional sebagai salah satu kebudayaan Indonesia yang mampu menarik perhatian dunia internasional, dengan diakuinya batik sebagai salah satu kerajinan warisan budaya oleh UNESCO (United Nations Educational, Scientific and Cultural Organization). Batik tulis adalah kain yang dihias dengan motif atau corak batik menggunakan tangan dengan alat canting tradisional. Pemakaian canting yang sulit bagi yang belum terbiasa (pemula) dan bisa membahayakan pengguna, membuat Balai Besar Kerajinan dan Batik pada tahun 2009 melakukan penelitian tentang rekayasa canting listrik (Cantrik) yang hasilnya bahwa penggunaan Cantrik ini lebih mudah dari pada penggunaan canting tradisional bagi orang yang belum pernah mencanting (menggunakan canting). Namun masih terdapat beberapa kekurangan dalam penggunaannya yaitu bentuknya masih besar dan masih terasa panas saat dipegang oleh karena itu perlu dilakukan penelitian lebih lanjut dengan membuat prototype Cantrik baru berdasarkan karakteristik kebutuhan pengguna menggunakan metode QFD (Quality Function Deployement).

Dalam pembuatan prototype Cantrik baru yang sesuai dengan keinginan pengguna perlu dilakukan suatu perencanaan tentang atributatribut apa yang diinginkan pengguna supaya pembuatan prototype Cantrik baru berhasil dengan baik. Penelitian ini mempunyai tujuan untuk membuat prototype Cantrik baru yang sesuai dengan keinginan pengguna dan mengevaluasinya.

Pada penelitian Balai Besar Kerajinan dan Batik selama dua tahun (1983-1985), dilakukan pengembangan canting batik tulis menggunakan 
sistem aliran lilin batik pada canting dengan pipa dengan tujuan mengurangi keborosan lilin batik. Inovasi lain pada canting dengan menggunakan rangkaian canting sederhana yang dapat memanaskan malam sehingga mencapai suhu tertentu sesuai set point dan menjaga kestabilan suhu malam dengan perangkat elektronik. Sehingga dapat meengendalikan suhu malam pada kondisi yang stabil, sedangkan pada canting yang tidak mengalami perubahan [1].

Balai Besar Kerajinan dan Batik melakukan penelitian tentang rekayasa Cantrik dengan mengolah data keinginan konsumen menggunakan metode QFD. Berdasarkan percobaan di lapangan keuntungan penggunaan cantrik adalah tempat kerja tidak kotor, gerakan tangan berkurang. Namun masih terdapat kekurangan saat dipegang masih terasa panas perlu diberi bahan isolasi lagi sehingga ukuran catrik menjadi lebih besar. Hal ini yang mendukung untuk dilakukan penelitian tentang Cantrik tersebut [2].

QFD merupakan suatu metode yang digunakan untuk membuat perencanaan produk dan dilakukan oleh suatu tim pengembang dengan mencari keinginan dan kebutuhan konsumen atau pelanggan. Mengevaluasi usahausaha untuk mencapai tujuan tersebut baik untuk pengembangan produk atau jasa. QFD merupakan praktek untuk merancang suatu proses sebagai tanggapan terhadap kebutuhan pelanggan. Beberapa aspek penting dari metode QFD adalah [3]: Fokus utama QFD adalah customer needs (kebutuhan konsumen) dan harapan-harapan konsumen terhadap produk tersebut. Semua anggota yang terlibat dalam organisasi/tim pengembangan produk dengan metode QFD akan berpengaruh terhadap produk. QFD sangat cocok jika diimplementasikan dengan concurent engineering.

QFD merupakan salah satu tool (metode) atau manajemen kualitas, yang diajukan untuk menggali keinginan, harapan konsumen berupa suara pelanggan atau Voice of Customer (VOC) akan suatu produk atau jasa sesuai yang diinginkan konsumen, dengan memperhatikan kemampuan pihak pengelola atau pihak industri.
Tujuan dari QFD sendiri tidak hanya memenuhi sebanyak mungkin harapan-harapan pelanggan, tapi juga berusaha melampaui harapan-harapan pelanggan sebagai cara untuk berkompetisi dengan saingannya.

Metode QFD memiliki beberapa tahap perencanaan dan pengembangannya yaitu [2]: Matrik Perencanaan Produk (House of Quality), Matrik Perencanaan Part (Part Deployment), Matrik Perencanaan Proses (Proses Planning) dan Matrik Perencanaan Produksi (Manufacturing Production Planning).

House of Quality memperlihatkan struktur untuk mendisain dan membentuk suatu siklus, dan bentuknya menyerupai sebuah rumah. Kunci input bagi matriks adalah kebutuhan dan keinginan konsumen. Informasi strategi produk dan karakteristik kualitas produk. Informasi lain yang terdapat di HOQ adalah nilai target HOQ yang mengandung beberapa bagian. Masingmasing bagian dapat dan harus disesuaikan agar dapat berfungsi dengan baik.

Gambar 1 menunjukkan bentuk umum matriks perencanaan produk atau rumah kualitas HOQ. Dalam gambar digunakan simbol huruf A hingga $F$ menunjukkan urutan pengisian bagian-bagian matriks perencanaan tersebut.

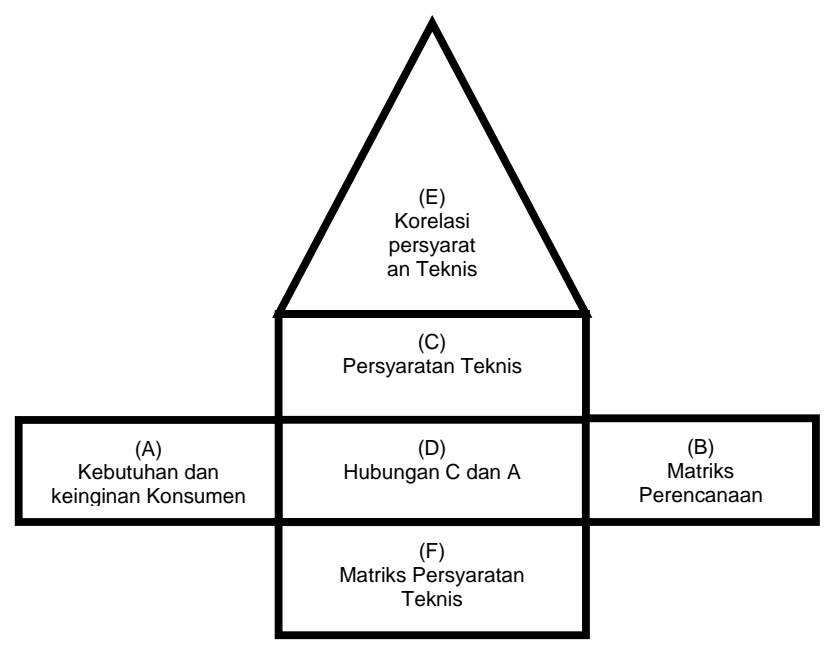

Gambar 1. House of Quality

Tahap-tahap dalam penerapan QFD secara efektif dibutuhkan enam fase, yaitu [2]: Tahap pertama persiapan dan perencanaan. Tahap kedua pengumpulan suara konsumen (voice of customer), penyusunan rumah kualitas (House of Quality) dengan menghitung tingkat 
kepentingan (Kepentingan absolute dan Kepentingan relatif, tingkat kepuasan (Customer Satisfaction Performance), penentuan Goal, menghitung Rasio pengembangan (Improvement Ratio), tingkat penjualan, bobot kepentingan (Raw Weight). Tahap Ketiga: respon teknis (Technical Respon). Tahap Keempat: Menentukan hubungan teknis dengan kebutuhan pelanggan terdapat empat kemungkinan hubungan dalam relationship matrix. Tahap Kelima : Korelasi Teknis. Tahap Keenam : Prioritas teknis.

Terdapatnya kekurangan dalam penelitian terdahulu oleh balai sehingga perlu dilakukan pembuatan prototype dari Cantrik. Sebelum dilakukan pembuatan prototype perlu diketahui tentang pendefinisian prototype yaitu sebagai sebuah penaksiran produk melalui satu atau lebih dimensi yang menjadi perhatian. Dengan definisi ini setiap wujud yang memperlihatkan sedikit aspek produk yang menarik bagi tim pengembang dapat ditampilkan sebagai sebuah prototype [4].

Membuat prototype merupakan proses pengembangan dari pendefinisian dan perkiraan-perkiraan dari sebuah produk. Beberapa prinsip berguna pemandu keputusan selama pengembangan produk. Prinsip-prinsip ini menunjukkan tentang keputusan-keputusan terhadap prototype mana yang harus dipilih dan memasukkan prototype kedalam rencana pengembangan adalah [5]: Prototype analitik, Prototype fisik untuk menemukan fenomena yang tidak dapat diduga, prototype dapat mengurangi risiko interasi yang merugikan, dapat memperlancar langkah pengembangan lainnya dan dapat merekonstruksi ketergantungan tugas.

\section{METODE PENELITIAN}

Penelitian ini dilakukan di Laboratorium Proses Produksi Jurusan Teknik Industri Universitas Widya Mataram Yogyakarta dengan fokus penelitian pembuatan prototype cantrik baru dan mengevaluasi hasilnya. Alat yang digunakan dalam penelitian ini adalah: Stopwatch, Camera digital, untuk mendokumentasikan proses pembuatan prototype, Kuesioner 1 dipakai untuk menentukan atribut/karakteristik kebutuhan pelanggan, Kuesioner 2. Kuesioner kepuasan dan kepentingan berdasarkan karakteristik kebutuhan pengguna untuk mengukur tingkat kepuasan dan kepentingan responden.

Kerangka penelitian ditunjukkan pada Gambar 2. untuk penjelasan setiap tahapan penelitian atau Langkah penelitian sebagai berikut: Identivikasi variabel terdiri dari Identifikasi kuisioner dan identifikasi sampel: identifikasi kuisioner pada penelitian ini dibagi menjadi dua bagian yaitu: bagian pertama berisi tentang data karakteristik responden yang memuat informasi nama, jenis kelamin, usia, pendidikan terakhir. Bagian kedua berisi tentang tanggapan responden terhadap cantrik saat ini yang datanya dipakai dasar dalam menentukan karakteristik (atribut) kebutuhan pengguna untuk membuat kuisioner II. Kuisioner II ini terbagi menjadi dua bagian yaitu bagian 1. Yang berisi tentang kepuasan responden terhadap cantrik pada saat sekarang dan bagian 2. Berisi tentang kepentingan responden terhadap cantrik tersebut.

Identifikasi Sampel, sampel yang dipakai dalam penelitian ini adalah: calon pengguna atau pemula yaitu seseorang yang belum pernah mencanting sebagai respondennya, jumlah sampel diambil sebanyak 35 orang atau responden, Usia sampel yang diukur adalah 1230 tahun, karena pemakaian cantrik tersebut diutamakan bagi anak-anak dan remaja sebagai generasi penerus. Jenis kelamin yang sebagai subyek dipilih berjenis kelamin perempuan dan laki-laki karena harapannya cantrik bisa dipakai oleh siapa saja yang berminat.

Pembuatan kuesioner berdasarkan karakteristik kebutuhan pengguna cantrik yang akan dipakai dalam penentukan kepuasan dan kepentingan konsumen, sebagai dasar dalam pembuatan prototype berdasarkan Tabel 1.

\begin{tabular}{llc}
\multicolumn{3}{l}{ Tabel 1. Atribut Kebutuhan Pengguna Cantrik } \\
\hline No & Karakteristik Kebutuhan Pengguna & Atribut \\
\hline 1 & Kebutuhan pengoprasian & A \\
2 & Dapat dipakai oleh siapapun & B \\
3 & Kesesuaian alat dengan kondisi kerja & C \\
4 & Dapat dipakai dengan alas atau tidak & D \\
5 & Tidak ada alat bantu (alat elektrikal) & E \\
6 & Proses penorehan malam lancar & F \\
7 & Perawatan alat mudah & G \\
8 & Penorehan malam dapat disesuaikan & H \\
\hline
\end{tabular}


Lanjutan Tabel 1. Atribut Kebutuhan Pengguna Cantrik

\begin{tabular}{llc}
\hline No & Karakteristik Kebutuhan Pengguna & Atribut \\
\hline 9 & Lama pemakaian diatas 2,5 menit (1 & $\mathrm{I}$ \\
& kali pengisian) & \\
10 & Kualitas produk yang dihasilkan baik & $\mathrm{J}$ \\
11 & Harga alat terjangkau & $\mathrm{K}$ \\
12 & Kualitas bahan bagus & $\mathrm{L}$ \\
13 & Tidak menetes saat digunakan & $\mathrm{M}$ \\
14 & Tidak panas saat digunakan & $\mathrm{N}$ \\
15 & Tidak lelah saat digunakan & $\mathrm{O}$ \\
16 & $\begin{array}{l}\text { Disain alat sesuai antropometri } \\
\text { tangan }\end{array}$ & $\mathrm{P}$ \\
17 & $\begin{array}{l}\text { Alat ringan sehingga mudah dibawa } \\
\text { kemana saja }\end{array}$ & $\mathrm{Q}$ \\
\hline
\end{tabular}

Langkah-langkah penelitian: pengisian kuesioner dilakukan oleh responden. Pengujian kuesioner, uji kecukupan data dan uji validitas hanya menunjukkan sejauh mana suatu alat pengukur itu mampu mengukur apa yang diukur. Pengumpulan data, meliputi data hasil kuesioner tentang kepuasan dan kepentingan responden yang akan dipakai dalam melakukan perancangan. Pengolahan data, pengolahan yang dilakukan untuk pengembangan produk adalah: Pengolahan data dari kuesioner 1 dengan menghitung prosentase pada setiap butir pertanyaan yang dipakai dalam penentuan atribut sebagai dasar pembuatan kuisioner 2 . Berdasarkan data dari kuisioner 2 yang telah diperoleh di lakukan pengujian data dan pengolahan data tentang tingkat kepentingan dan tingkat kepuasan pengguna/responden sebagai dasar dalam perancangan QFD. Perancangan QFD, yang diawali dengan pembentukan diagram HOQ secara berurutan dengan menterjemahkan kebutuhan konsumen kedalam langkah-langkah operasional. Langkah-langkah operasional yaitu: melakukan identifikasi semua kebutuhan dan keinginan konsumen terhadap produk yang ada; mengidentifikasikan tingkat kepentingan konsumen untuk masing-masing karakteristik konsumen yang telah ada; menerjemahkan seluruh kebutuhan dan keinginan konsumen (Whats) kedalam karakteristik desain (Hows); menentukan hubungan yang terjadi antara masing-masing karakteristik konsumen dengan karakteristik desain; menentukan target perusahaan terhadap masing-masing karakteristk desain yang ada; membentuk matrik korelasi yang menunjukkan hubungan antar masing-masing karakteristik desain yang ada; disain produk perusahaan sendiri dibandingkan dengan produk-produk pesaing berdasarkan karakteristik seperti halnya diatas semua desain produk yang ada; dengan menetapkan nilai-nilai yang berupa angka pada matriks hubungan keinginan konsumen dan karakteristik desain maka seluruh penilaian dapat disusun berdasarkan kepentingan relatif dari setiap kebutuhan dan keinginan konsumen.

Pembuatan Prototype yang dilakukan adalah menentukan komponen-komponen apa saja yang akan dipakai dalam pembuatan Cantrik tersebut dan membuat gambar serta spesifikasinya dari komponen tersebut. Kemudian membuat komponen dengan mengorderkan kepada bengkel proses setelah itu dilakukan perakitan dari komponenkomponen tersebut.

Langkah selanjutnya adalah melakukan pembahasan dan melakukan pengujian Cantrik tersebut serta membuat kesimpulan. Untuk lebih jelasnya dapat dilihat dalam kerangka penelitian sesuai dengan Gambar 2.

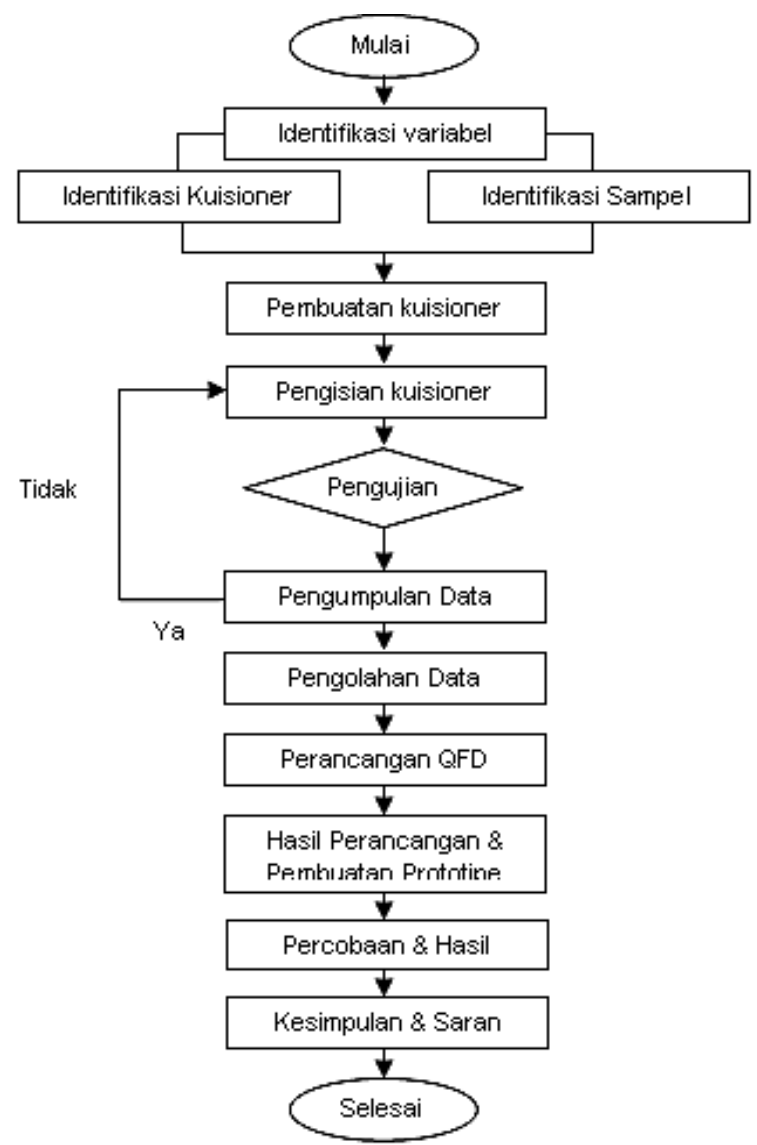

Gambar 2. Diagram Alir Penelitian 


\section{HASIL DAN PEMBAHASAN}

Data yang diperoleh dalam penelitian ini berupa data hasil dari penyebaran kuesior 1 tanggapan pengguna terhadap Cantrik lama sebagai dasar penentuan atribut yang mau dipakai dalam pembuatan Kuesioner 2 yaitu kuesioner tentang kepentingan dan kepuasan pengguna cantrik lama serta berdasarkan atribut kebutuhan pengguna cantrik pada Tabel 1 akan diperoleh hasil/data tersebut sesuai dengan Tabel 2.

Penentuan Karakteristik kebutuhan pengguna untuk QFD dari ke 17 atribut berdasarkan hasil rata-rata Tingkat Kepuasan dan Tingkat Kepentingan dalam Tabel 2 maka atribut yang dipakai dalam pembuatan HOQ, berdasarkan atribut yang mempunyai nilai ratarata tingkat kepentingannya di atas 4,5. Seperti ditunjukkan dalam Tabel 3.

Terdapat 10 atribut yang dipilih kemudian dipakai dalam penyusun rumah kualitas yang hasilnya sesuai dengan Gambar 3. Atributatribut yang dipakai adalah kemudahan pengoperasian, dapat dipakai oleh siapapun, lama pemakaian di atas 2,5 menit, kualitas produk yang dihasilkan baik, harga alat terjangkau, tidak menetes saat digunakan, tidak panas saaat digunakan, tidak lelah saat digunakan dan desain alat sesuai dengan antropometri.

Penentuan spesifikasi akhir, Prototype Cantrik yang dibuat nantinya akan lebih mudah penggunaanya, aman dalam penggunaannya, dan menarik digunakan (Semiotika produk). Prototype Cantrik baru dalam cara memegang masih sama pada Cantrik lama yaitu seperti memegang pena, namun cara pengoperasiannya berbeda yaitu tidak dengan menekan alat tersebut hanya dengan menggerakkan tuas pengotrol yaitu menaikkan dan menurunkan tuas pengontrolnya.

Kriteria dan Pembuatan Prototype Cantrik. Penentuan diameter prototype Cantrik yaitu produk mudah digenggam (menyesuaikan ukuran tanggan pengguna) hal ini berdasarkan dengan ketebalan grip 8-13 mm yang diizinkan dan berdasarkan hasil pengembangan dari pistol grip menurut [8], bahwa tebal dari grip adalah 32,7 mm serta berdasarkan data antropometri telapak tangan orang Indonesia yang didapat dari interpolasi data Nurmianto bahwa besar diameter genggaman (maksimum) untuk peremuan pada 95 persentil adalah $49 \mathrm{~mm}$ [9]. Berdasarkan data tersebut pembuatan prototype Cantrik menpunyai ukuran diameter sebesar 24,8 $\mathrm{mm}$ hal ini sesuai dengan ukuran diameter dari pegangan Cantrik dalam [7].

Tabel 2. Rata-rata Tingkat Kepuasan dan Tingkat Kepentingan Responden

\begin{tabular}{clcc}
\hline \multirow{2}{*}{ No } & \multicolumn{1}{c}{ Atribut } & $\begin{array}{c}\text { Tingkat } \\
\text { Kepuasan }\end{array}$ & $\begin{array}{c}\text { Tingkat } \\
\text { Kepentingan }\end{array}$ \\
\hline 1 & Kemudahan pengoperasian alat (A) & 2,69 & 4,6 \\
2 & Dapat dipakai oleh siapa saja (B) & 2,63 & 4,68 \\
3 & Kesesuaian alat dengan kondisi kerja (C) & 2,49 & 4,29 \\
4 & Dapat dipakai dengan alas atau tidak (D) & 2,06 & 4,57 \\
5 & Tidak ada alat bantu (alat elektrikal) (E) & 2,51 & 4,14 \\
6 & Proses penorehan malam lancar (F) & 3,69 & 4,43 \\
7 & Perawatan alat mudah (G) & 2,09 & 4,2 \\
8 & Penorehan malam dapat disesuaikan (H) & 2,23 & 4,4 \\
9 & Lama pemakaian diatas 2,5 menit (1 kali pengisian) (I) & 3,94 & 4,51 \\
10 & Kualitas produk yang dihasilkan baik (J) & 2,51 & 4,69 \\
11 & Harga alat terjangkau (K) & 3,43 & 4,6 \\
12 & Kualitas bahan bagus (L) & 2,11 & 4,29 \\
13 & Tidak menetes saat digunakan (M) & 3,23 & 4,51 \\
14 & Tidak panas saat digunakan (N) & 2,46 & 4,6 \\
15 & Tidak lelah saat digunakan (O) & 294 & 4,49 \\
16 & Disain alat sesuai antropometri tangan (P) & 246 & 4,8 \\
17 & Alat ringan sehingga mudah dibawa kemana saja (Q) & 251 & 4,29 \\
\hline
\end{tabular}


Tabel 3. Atribut Karakteristik Kebutuhan Pengguna Dalam QFD

\begin{tabular}{llcc}
\hline No & \multicolumn{1}{c}{ Atribut } & Tingkat Kepuasan & Tingkat Kepentingan \\
\hline 1 & Kemudahan pengoperasian alat (A) & 2,69 & 4,6 \\
2 & Dapat dipakai oleh siapa saja (B) & 2,63 & 4,68 \\
3 & Dapat dipakai dengan alas atau tidak (D) & 2,06 & 4,57 \\
4 & Lama pemakaian di atas 2,5 menit (1 kali pengisian) (I) & 3,94 & 4.51 \\
5 & Kualitas produk yang dihasilkan baik (J) & 2,51 & 4,89 \\
6 & Harga alat terjangkau (K) & 3,43 & 4,6 \\
7 & Tidak menetes saat digunakan (M) & 3,23 & 4,51 \\
8 & Tidak panas saat digunakan (N) & 2,46 & 4,6 \\
9 & Tidak lelah saat digunakan (O) & 2,94 & 4,49 \\
10 & Disain alat sesuai antropometri tangan (P) & 2,45 & 4,8 \\
\hline
\end{tabular}

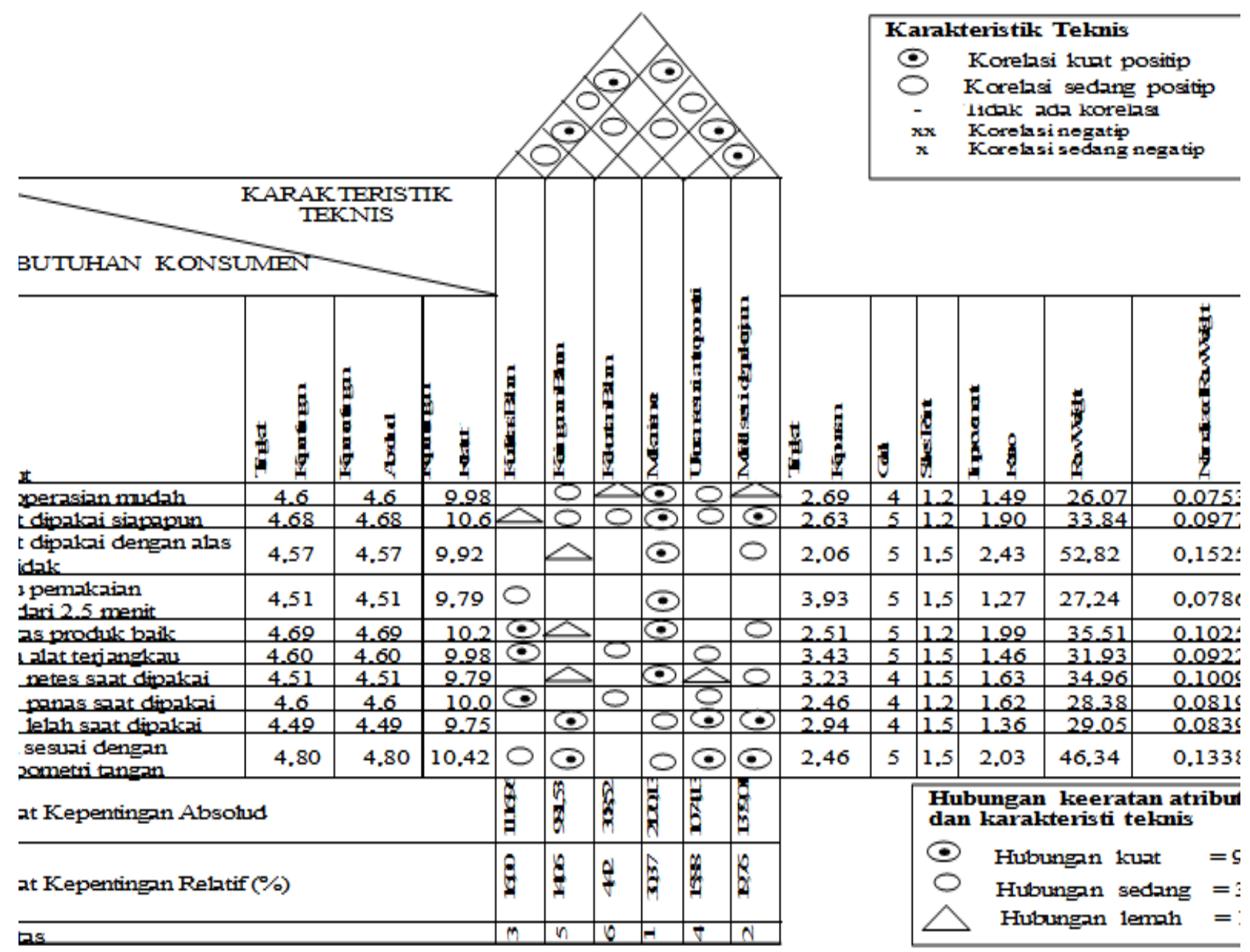

Gambar 3. House of Quality

Penentuan panjang prototype Cantrik berdasarkan panjang minimum grip produk 10 $\mathrm{cm} \quad(100 \mathrm{~mm})$ yang diizinkan dengan genggaman precision grip dan sesuai data serta pertimbangan volume malam dan panjang dari bagian-bagian ukuran prototype Cantrik, maka panjang dari prototype tersebut adalah 200,02 $\mathrm{mm}$ hal ini sesuai dengan panjang Cantrik sesuai dengan pendapat Lestariningsih [7].
Kriteria penggunaan prototype Cantrik, bahwa produk aman bagi pengguna malam tidak tumpah dan menetes, gengaman alat tidak begitu panas, penggunan elemen pemanas dengan mengunakan listrik tidak membahayakan pengguna, dapat dipakai siapa saja, produk mudah digunakan (tidak membutuhkan keahlian khusus atau pengalaman dalam menggunakan produk), 
mekanisme mudah: Cara mengoperasikan produk mudah dipahami karena menyerupai penggunaan pena dan malam yang keluar dapat dikontrol, sehingga tidak menetes pada tempat yang tidak dihendaki untuk memudahkan pengisian kembali malam dalam bentuk batangan.

Bagian-bagian dalam pembuatan prototype Cantrik, terdiri dari tiga bagian yaitu bagian atas, bagaian tengah dan bagian bawah yang terdiri dari 15 komponen.

Pembuatan Prototype Cantrik, dalam hal ini pembuatan komponen-komponen prototype Cantrik baru melalui jasa bengkel setelah komponen-komponen itu jadi kamudian dilakukan perakitan berdasarkan kebutuhan pada prototype Cantrik tersebut yaitu:

Bagian atas prototype Cantrik yang terdiri dari komponen (1) sampai komponen (9) yaitu komponen dudukan listrik, tempat elektrik, nut tempat elektrik, tuas pengontrol, nut, ring, tutup atas, ring tabung atas dan spring.

Bagian tengah prototype Cantrik yang terdiri dari komponen (10) sampai komponen (14) yaitu komponen tempat elemen pemanas, tabung malam, ring tabung malam, penyekat panas dan chasing.

Bagain bawah prototype Cantrik hanya terdiri dari satu komponen saja yaitu komponen (15) cucuk.

Bagian-bagian pada prototype Cantrik bila digabungkan atau dirangkai menjadi satu kesatuan yang berupa Prototype Cantrik yang hasilnya seperti pada Gambar 4 hal ini sesuai dalam pendapat Tantowi [8].

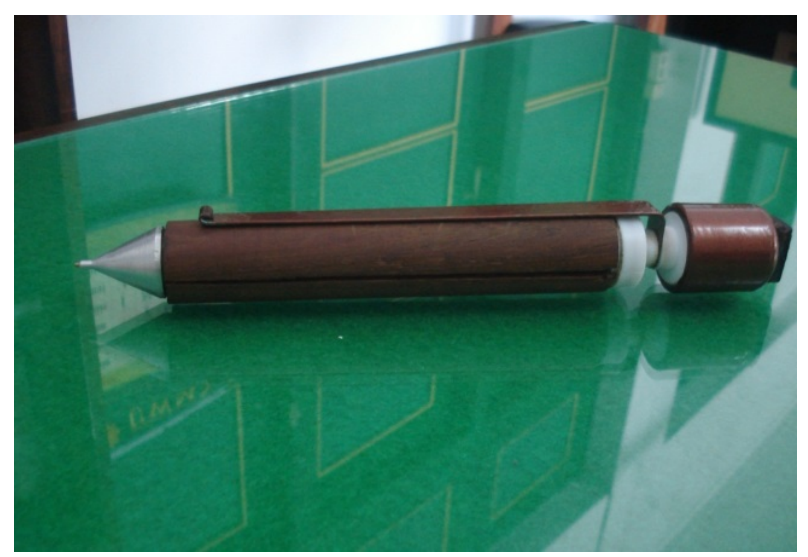

Gambar 4. Prototype Cantrik baru
Percobaan Prototype Cantrik sebelum dilakukan percobaan terlebih dahulu membuka tutup tabung bagian atas kemudian memasukkan malam yang sudah berbentuk refill batangan dan menutup kembali. Langkah selanjutnya menyambungkan arus listrik kedalam dudukkan tempat elektrik pada prototype Cantrik dan menyetel besar kecilnya arus yang masuk sampai mencapai suhu stabil yaitu bila suhu malam sudah mencapai suhu $80^{\circ} \mathrm{C}$, setelah suhu malam tercapai kemudian dilakukan percobaan yang menghasilkan goresan malam.

Setelah dilakukan percobaan diperoleh bahwa dengan satu kali pengisian akan mendapatkan 35 sampai 38 goresan malam pada kain dengan masing-masing goresan panjangnya 1 meter sesuai dengan cucuk Klowong. Hasil goresannya setelah dilakukan pengecekan dinyatakan bahwa hasil goresannya mirip dengan goresan canting tradisional karena hasil cantingannya bisa tembus kebawah "ngawat".

\section{KESIMPULAN}

Telah dibuat prototype Cantrik baru yang sesuai dengan keinginan pengguna yang mempunyai diameter sebesar 24,8 mm dan panjang prototype Cantrik adalah 200,02. Sedangkan hasil dari pengujiannya atau evaluasi dan percobaannya adalah "ngawat" sesuai dengan hasil proses tradisional (dengan menggunakan canting tradisional). Serta saat penggunaannya lebih mudah, fleksibel, aman, nyaman dan menjadikan tempat pencantingan lebih bersih namun masih sedikit panas. Agar diteliti lebih lanjut tentang prototype masalah menentuan bahan dan lapisan tersebut yaitu masalah penentuan bahan dan ketebalan lapisan dari penyekat panas untuk mendapatkan prototype Cantrik yang lebih baik performanya.

\section{DAFTAR PUSTAKA}

[1]. Balai Besar Kerajinan dan Batik, 2009, Rekayasa Canting Listrik, Laporan penelitian tidak diterbitkan, Yogyakarta Departemen Perindustrian.

[2]. Cohen, L., 1995, Quality Function Deployement: How to Make QFD Work 
For You, Addition - Wesley publishing Company, Massachuset.

[3]. Haryanto, F. T., 2007, Pengendali kestabilan Suhu Kawat Pemanas pada Canting Batik, Skripsi. tidak diterbitkan. Yogyakarta : Fakultas teknik. Universitas Gadjah Mada.

[4]. Ulrich, K.t. dan Eppinger, S.D., 2001, Perancangan dan Pengembangan Produk, Penerbit Salemba Teknika. Jakarta.

[5]. Lestariningsih, S. 2012. Pengembangan CANTRIK Yang Ergonomis, Tesis. tidak diterbitkan Yogyakarta : Fakultas teknik. Universitas Gadjah Mada.

[6]. Widodo, I. Dj., 2003, Perencanaan dan Pengembangan Produk (Product Planning and Design), UII Press. Yogyakarta.
[7]. Lestariningsih, S. Dharmastiti, R., Moyoretno, B. 2012, Pengembangan CANTRIK Yang Ergonomis, Prosiding Seminar Nasional Perkembangan Riset dan Teknologi di Bidang Industri ke 18. Fakultas teknik. Universitas Gadjah Mada .Yogyakarta Mei 2012.

[8]. Tontowi,A.E., dkk, Perancangan dan Pengembangan Pistol Grip Berdasarkan Antropometri Tangan Prajurit TNI, Prosiding Seminar Nasional Ergonomi aplikasi Ergonomi Dalam Dunia Industri Jogjakarta, 5 April 2003.

[10]. Nurmiyanto, E., 1998, Ergonomi Konsep Dasar dan Aplikasinya, Edisi Pertama, Guna Widya. 